\title{
Self-employment and reason for migration: are those who migrate for asylum different from other migrants?
}

\author{
Zovanga L. Kone • Isabel Ruiz • Carlos Vargas-Silva
}

\begin{abstract}
This paper explores differences in the likelihood of engaging in self-employment among migrants who moved for different reasons to the UK. The results suggest that, conditional on being in employment, those who initially migrated for asylum reasons are six percentage points more likely to engage in selfemployment than the UK-born, while those who migrated for work reasons are not significantly different from UK-born workers in this regard. We also find that mediating factors, such as the presence of networks and years since migration, relate differently to the likelihood of self-employment for each group of migrants. Finally, there are also differences when looking at the number of persons employed by the self-employed and the skill
\end{abstract}

Electronic supplementary material The online version of this article (https://doi.org/10.1007/s11187-019-00311-0) contains supplementary material, which is available to authorized users.

Z. Kone $\cdot$ C. Vargas-Silva $(\bowtie)$

Centre on Migration, Policy and Society, University of Oxford, 58

Banbury Rd, Oxford OX2 6QS, UK

e-mail: carlos.vargas-silva@ compas.ox.ac.uk

Z. Kone

e-mail: zlk2@le.ac.uk

Z. Kone

University of Leicester School of Business, University of Leicester, 223 London Road, LE2 1ZE Leicester, UK

I. Ruiz

Blavatnik School of Government, Harris Manchester College, University of Oxford, Oxford OX1 2JD, UK

e-mail: isabel.ruiz@bsg.ox.ac.uk level associated with the activity of self-employment. Those who migrated for asylum are not significantly different from the UK-born in their likelihood of employing someone else, while those who migrated for work are two percentage points less likely to employ others relative to the UK-born.

Keywords Self-employment $\cdot$ Migrants $\cdot$ Refugees · United Kingdom

JEL codes $\mathrm{J} 61 \cdot \mathrm{R} 23 \cdot \mathrm{L} 26$

\section{Introduction}

Are migrants more entrepreneurial than the native-born? Are they more likely to be self-employed? These questions have captivated the attention of academics and have become part of a flourishing area of research (Hart and Acs 2011; Jansen et al. 2003; Levie and Smallbone 2009; OECD 2010). There is evidence suggesting that foreign-born individuals tend to have higher propensity of entrepreneurship compared to the nativeborn (Kerr and Kerr 2017; Vandor and Franke 2016). In fact, recent evidence points to an increasing trend in self-employment rates and new business formation among the foreign-born in many countries, but a declining trend among the native-born (Fairlie and Lofstrom 2015).

Differences in entrepreneurship between migrants and native-born individuals may reflect labour market discrimination, differences in language skills, the 
existence of ethnic "enclave" economies, the selfselection process involved in migration, the temporariness of the migration experience and the likelihood of returning home and differences in risk aversion, among others. Discrimination in the labour market can increase returns to self-employment relative to waged employment (Clark and Drinkwater 2010; Fairlie and Meyer 1996). Ethnic enclaves provide access to markets for culture-specific goods and services, in which linguistic factors and culture-specific knowledge play a role (Miera 2008; Zhou 2004). More entrepreneurial individuals are more likely to migrate in the first place, and selective immigration policies geared towards attracting skilled migrants could be an augmenting factor (Borjas 1982). A higher likelihood of returning home might induce some migrants to enter self-employment in order to accumulate financial, human or social capital to be used once back to their home countries (Brück et al. 2018). Finally, differences in the degree of risk aversion between migrants and natives can lead to differences in the likelihood of engaging in entrepreneurial activities (Batista and Umblijs 2014; McMullen and Shepherd 2006; Ramoglou and Tsang 2016).

While the literature provides interesting insights on differences in entrepreneurship propensities between migrants and the native-born, it has largely ignored the heterogeneity of reasons for immigration among the foreignborn population. ${ }^{1}$ Reflecting on the case of the USA, Kerr and Kerr (2017) suggest that a key limitation of the evidence is that we "lack a clear picture of how the successful immigrant founders enter the United States, which can be for reasons as diverse as schooling, employment, family reunification, and more". This statement would also hold true for most countries around the world; it highlights a key gap in the literature: reason for immigration may correlate with opportunities for waged employment and other factors that affect the choice of economic activity of individuals, including the legal constraints they face when making their choices. While some migrants move to a country to become entrepreneurs, most move for other reasons and engage in entrepreneurship after several years of residence in the host country (Kerr and Kerr 2017).

This study explores the relationship between initial reason for immigration and the propensity of selfemployment among migrants. We ask: are those who initially migrated for asylum, family, study and work

\footnotetext{
${ }^{1}$ Among the few exceptions to this is the work of Constant and Zimmerman (2005) for Denmark and Germany.
}

reasons as likely to engage in self-employment as the native-born? What is the potential role of immigration and related policies in creating these differences? Is the effect of mediating factors (e.g. networks, length of residence) on self-employment the same for all groups?

While self-employment on its own only captures one aspect of entrepreneurship, identifying how selfemployment rates differ across those who migrated for different reasons is important in order to understand the consequences of immigration policy choices. For example, restricting or expanding one type of migration (e.g. student and work visas) can have a different impact on entrepreneurship and business formation than restricting or expanding other types (e.g. family visas, refugee resettlement). Exploring the role of reason for immigration can also inform the development of interventions directed at boosting entrepreneurial potential among the different migrant groups.

A number of studies have explored the role of ethnicity in self-employment patterns across subgroups of the population (Clark and Drinkwater 2000, 2010; Clark et al. 2017; Levie 2007), and others have looked at the role of the region of origin of the migrants (Andersson and Hammarstedt 2015; Blume et al. 2009; Hammarstedt 2004). Our analysis complements these studies and explores whether individuals from the same ethnic group and region of origin who migrated for different reasons have different propensities of engaging in self-employment.

Furthermore, we explore the mediating roles of length of residence in the host country and networks of compatriots in determining differences in self-employment rates across the various migrant groups we look at. If there is a strong degree of integration into the host society, those migrants who have spent longer time in the host country are likelier to converge in their self-employment rates to those of natives. However, we expect reason for immigration to influence the pace of migrant integration. Access to networks can increase the likelihood of self-employment but can also increase the likelihood of waged employment. Which of these two effects dominate could vary substantially across those with different reasons for immigration.

Our analysis is based on 2007-2018 data from the United Kingdom (UK), a country which hosts the fifth largest stock of migrants worldwide (World Bank 2018). The UK's migrant population, estimated at 9.4 million or $14 \%$ of the population in 2017 (Office for National Statistics 2018), is diverse in terms of country of origin and reason for immigration. Adding the fact that the UK also has one of the largest economies in the world and 
that its immigration policy is likely to change in the near future because of Brexit (Vargas-Silva 2016b), it is an ideal case for exploration. While there is research on differences in the wages and hours worked of migrants in the UK by reason for immigration (e.g. Ruiz and Vargas-Silva 2018), issues related to self-employment and reason for immigration remain unexplored. Many high-income countries have immigration systems similar to that of the UK (OECD 2018). Our findings may therefore also inform debates elsewhere.

\section{Conceptual background}

Our analysis compares individuals who migrated for four different reasons, all relative to the UK-born. We refer to these groups as asylum migrants, economic migrants, family migrants and study migrants. These categories refer to reason for initial immigration, not actual visa status or main activity (e.g. study migrants are not current students). We draw on Clark and Drinkwater (2000) and others, who have explored differences in self-employment rates between majority and minority ethnic groups, to define our conceptual approach. The underlying idea is that a series of "push" and "pull" factors determine the decision to enter selfemployment versus waged employment. In particular, we focus on factors related to the potential rewards from engaging in waged employment versus selfemployment.

In order to facilitate the discussion, we denote the average earnings from waged employment (i.e. earnings from working as an employee) of any group $g$ as $w_{g}$. These values represent average earnings of the group members (i.e. asylum migrants, economic migrants, family migrants, study migrants, and the native born) after controlling for their key socio-demographic characteristics. In other words, the earnings reflect the degree to which factors related to reason for immigration affect the reward to waged employment. The evidence for the UK suggests that $w_{g}$ varies by reason for immigration (Ruiz and Vargas-Silva 2018). As summarised in Fig. 1, the empirical evidence shows that, controlling for socio-demographic factors, study migrants tend to have higher hourly earnings, followed closely by economic migrants. Family and asylum migrants have substantially lower hourly earnings. These differences could relate to factors that involve direct discrimination but could also reflect other aspects such as a lower degree of familiarity with workplace culture in the host country.

Individuals also have the alternative of engaging in self-employment and the reward for doing so is given by a function $\left(\pi_{g}\right)$, which depends on a series of factors that are common across groups and a series of factors that are group-specific. The group-specific factors might reflect aspects such as the influence of networks, which can facilitate transactions, provide loans and serve as a customer base, fluency in a particular language and entrepreneurial culture. There is scarce evidence for the UK, or any other similar economy, on differences in earnings from self-employment among those who initially migrated for different reasons. We therefore do not have a clear a priori empirical expectation about how $\pi_{g}$ would vary by reason for immigration.

The likelihood to enter into self-employment $(s)$ for those in group $g$ (i.e. asylum migrants, economic migrants, family migrants, study migrants or native-born) depends on $w_{g}, \pi_{g}$, observable characteristics $(\boldsymbol{X})$ such as age, gender, education and unobserved factors $(\boldsymbol{u})$ which could include factors such as innate preferences for a certain type of activity. ${ }^{2}$ We summarise these interlinkages using the following expression:

$s_{g}=f\left(\pi_{g}, w_{g}, \boldsymbol{X}_{g}, \boldsymbol{u}_{g}\right)$

In general, $s_{g}$ is increasing in $\pi_{g}$ and decreasing in $w_{g}$. This idea forms the backbone of our hypotheses. ${ }^{3}$

We start the discussion by exploring the overall premise of the paper, which is that reason for immigration affects the likelihood of self-employment and this creates differences across groups. The main implication of this premise is that $s_{g}$ varies by reason for immigration. As explained above, there is no evidence on differences in earnings from self-employment among those who migrated for different reasons, but there is evidence on differences in the rewards to waged employment. Using the ranking of earnings from Fig. 1 (i.e. study $>$ economic $>$ family $>$ asylum), Table 1 provides a summary of the predictions from nine possible scenarios based on the relationship between $\pi_{g}$ and $w_{g}$ across groups. We use study and asylum migrants for illustration,

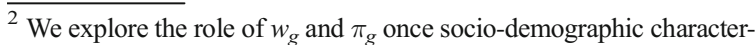
istics have been controlled for. Previous studies have shown that factors such as education play a role in determining the likelihood of selfemployment (Davidsson and Honig 2003).

${ }^{3}$ The pressure to remit money home may affect the election of economic activity, but it is unclear how this relates to reason for immigration (Vargas-Silva 2017).
} 
Fig. 1 Hourly earnings gap between migrants and the UKborn, by reason for immigration. Estimated using the values from Ruiz and Vargas-Silva (2018). Two standard error confidence interval included

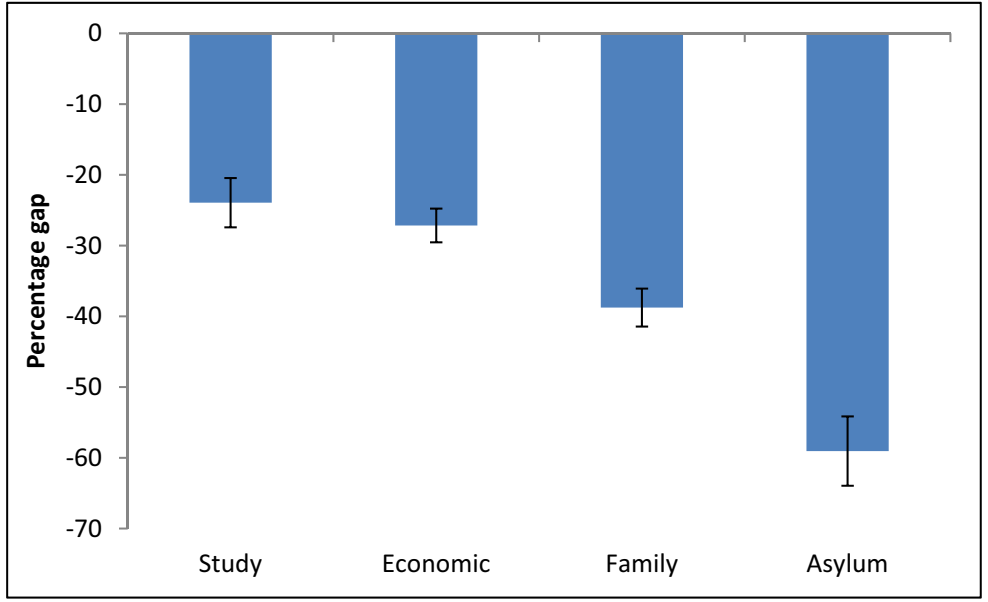

respectively denoted with subscripts ST and AS. For example, $w_{\mathrm{ST}}$ is the reward to waged employment for study migrants, while $w_{\mathrm{AS}}$ is the reward to waged employment for asylum migrants. In order to facilitate the discussion, we define two additional terms as follows:

$\operatorname{Gap}_{-} w=w_{\mathrm{ST}}-w_{\mathrm{AS}}$

$\mathrm{Gap}_{-} \pi=\pi_{\mathrm{ST}}-\pi_{\mathrm{AS}}$

In all scenarios in Table 1, we follow the existing evidence and assume that Gap _ $w>0{ }^{4}$

In the first row of Table 1, the average earnings gap in waged employment between study and asylum migrants is greater than the earnings gap in self-employment. This leads to asylum migrants being more likely to engage in self-employment compared to study migrants. In other words, if differences in the rewards to selfemployment across groups are sufficiently small, we would then expect workers who migrated for asylum reasons to have higher self-employment rates than workers who migrated for study reasons. Note that this is the case even if study migrants earn more from selfemployment than asylum migrants (i.e. scenario $1 \mathrm{C}$ ). In the situation in the second row, the gaps in earnings from self-employment and waged employment are the same across the two groups. In such case, we would expect to see no major differences in the likelihood of self-employment across groups. Finally, the last row of Table 1 depicts a scenario where the gap in earnings

\footnotetext{
$\overline{{ }^{4} \text { As we assume that Gap } \_w}>0$, it follows that $\pi_{\mathrm{ST}}>\pi_{\mathrm{AS}}$ in rows 2 and 3 of Table 1 .
}

from self-employment between study and asylum migrants is greater than the gap in waged employment. Such case leads to study migrants being more likely to go into self-employment compared to asylum migrants. These two last scenarios are less likely. We do not have estimates of the gap in earnings from self-employment between study and asylum migrants, but we know that the gap in waged employment between the two groups is large (Fig. 1). Based on the discussion above we formulate Hypothesis 1:

Hypothesis 1 (H1): The propensity to engage in self-employment will be higher for groups of migrants that are less rewarded in waged employment (e.g. asylum migrants) than for those that are more rewarded (e.g. study migrants).

Our second hypothesis relates to the role of time spent in the country. As individuals stay longer in the host country, we would expect their integration into society to lead to convergence in self-employment rates with the native-born (Clark et al. 2017). However, this convergence process is unlikely to be equal for all groups based on reason for immigration. We would expect recent migrants from groups that face greater wage penalties in the labour market, and that typically converge more gradually in waged earnings to the native-born (Ruiz and VargasSilva 2018), to converge faster in terms of self-employment. This leads to the second hypothesis:

Hypothesis 2 (H2): Migrant groups that are less rewarded in waged employment (e.g. asylum migrants) will converge faster to the native-born in 
Table 1 Group more likely to engage in self-employment based on different scenarios

\begin{tabular}{|c|c|c|c|c|c|}
\hline & & & \multicolumn{3}{|c|}{ Gap in reward to self-employment } \\
\hline & & & $\begin{array}{l}\text { Gap }_{-} \pi<0 \\
\text { (A) }\end{array}$ & $\begin{array}{l}\mathrm{Gap}_{-} \pi=0 \\
\text { (B) }\end{array}$ & $\begin{array}{l}\mathrm{Gap}_{-} \pi>0 \\
\text { (C) }\end{array}$ \\
\hline \multirow[t]{3}{*}{ Gaps in rewards } & (1) & $\mathrm{Gap}_{-} w>\mathrm{Gap}_{-} \pi$ & Asylum & Asylum & Asylum \\
\hline & $(2)$ & $\mathrm{Gap}_{-} w=\mathrm{Gap}_{-} \pi$ & N/A & N/A & Equal \\
\hline & (3) & $\mathrm{Gap}_{-} w<\mathrm{Gap}_{-} \pi$ & N/A & N/A & Study \\
\hline
\end{tabular}

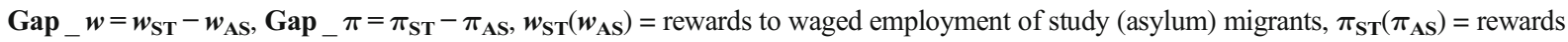
to self-employment of study (asylum) migrants

their propensity to engage in self-employment, compared to those that are more rewarded (e.g. study migrants).

Our third hypothesis relates to the influencing role of compatriot networks in determining self-employment. Compatriot concentration at the local level may affect the likelihood of engaging in self-employment for several reasons, including possible consumer discrimination against self-employed individuals (Borjas and Bronars 1989). For instance, consumers could prefer buying goods and/or services from compatriots due to unobserved reasons such as perceived quality or reliability. In addition, self-employment often depends on the availability of capital and access to compatriot networks may alleviate constraints to accessing finance (Martín-Montaner et al. 2018; Volery 2007).

The presence of compatriot networks and their possible effect on self-employment versus waged employment is likely to differ across individuals who migrated for different reasons. In particular, the presence of networks could also result in more opportunities for waged employment (Granovetter 1995). For instance, there is evidence that migrants often work in businesses owned by other migrants (Hansen and Cardenas 1988; Min 1989).

While networks can facilitate both waged and selfemployment, there is no a priori reason to expect that the presence of networks will reverse the dynamics which led to the formulation of H1. In fact, we would expect the facilitating role of networks to magnify the impact of differences in the reward to waged employment and self-employment. In other words, groups with more opportunities in waged employment are more likely to use their network of compatriots to obtain waged employment, while those with fewer opportunities can use this same network to enter into self-employment. This leads to our next hypothesis:
Hypothesis 3 (H3): Compatriot concentration at the local level is more likely to be positively associated with self-employment for those groups that are less rewarded in waged employment (1.e. asylum migrants) than for those that are more rewarded (e.g. study migrants).

We also expect labour market restrictions related to the UK's immigration policy to affect the selfemployment rates of different migrant groups. Overall, these restrictions correspond to a combination of nationality and reason for immigration. The main distinction lies between nationals of member states of the European Union (EU) and nationals of non-EU countries. EU nationals have unrestricted rights to engage in both employment and self-employment. For migrants coming from outside the EU, access to waged employment and self-employment are strongly influenced by route of entry, at least in the immediate years after arrival. ${ }^{5}$ Based on current UK law, family migrants from outside the EU have mostly unrestricted legal access to waged employment and self-employment from the moment they move to the UK. Current rules also mean that students who are non-EU nationals have limited legal access to waged employment (e.g. parttime only) while they are studying and are excluded from self-employment. For non-EU nationals, there are visas that include options for waged and self-employment. However, the main visa category that allows self-employment for this group (i.e. Tier 1 visa) is strongly restricted.

After some years in the country, non-EU nationals are eligible for indefinite leave to remain and this will

\footnotetext{
${ }^{5}$ See Vargas-Silva (2016a) for information on policies used to regulate migration for work from outside the EU. See Sumption and VargasSilva (2019) for information on family reunification policies.
} 
provide them with full access to both waged and selfemployment. ${ }^{6}$ Short-term legal restrictions upon arrival for those coming from outside the EU for work and study reasons will impact how these individuals interact with the labour market in the short-term and could also lead to different employment trajectories in the long term (including the likelihood of self-employment). This leads to our last hypothesis:

Hypothesis 4 (H4): The propensity to engage in self-employment will be higher for study and work migrants coming from EU countries than for study and work migrants coming from non-EU countries.

\section{Data and methodology}

We use the quarterly Labour Force Survey (LFS) of the UK for the analysis. The LFS is the largest household survey in the UK, and it is representative of the population. Our analysis covers the period from Q2 2007 to Q1 2018 (44 quarters). The survey contains a question on reason for immigration, which was introduced as a one off in Q2 2008 and permanently from Q1 2010. We take advantage of the rotatory nature of the survey and assign individuals who were surveyed in 2007 and 2009 the responses they provided about their reason for immigration in 2008 or in 2010.

We define "natives" as UK-born individuals and group the foreign-born by reason for migrating to the UK: asylum, family re-unification, study, work and other. Reason for immigration refers to the main reason for moving to the UK. Respondents can only select one category. One potential concern with the analysis is that there could be measurement error in the reporting of reason for immigration. Previous research (i.e. Ruiz and Vargas-Silva 2018) suggests that this variable works relatively well in capturing the actual migration route of certain groups such as those who migrated for asylum. In addition, as explained above, these categories refer to reason for initial immigration, not actual visa status or main activity. For instance, the large majority of asylum migrants no longer have refugee status and are UK citizens or have indefinite leave to remain. Likewise, study migrants are not current students, as

\footnotetext{
${ }^{6}$ For example, currently most non-EU nationals with work visas have to wait for 5 years in order to apply for indefinite leave to remain.
}

we exclude those enrolled in educational programmes from the analysis. These individuals initially came to the UK for study reasons and subsequently stayed in the country.

The sample is limited to employed respondents between the ages of 25 and 64 . By restricting our sample to employed individuals, we abstain from the discussion about the determinants of labour market participation for each of the groups. We recognise that this is an important topic, but the issues affecting the decision to enter employment and those affecting the choice between self-employment and waged employment are not the same and we want to focus on the latter set of issues. For foreign-born respondents, we impose the additional restriction that migration must have occurred at age 16 or later. This restriction limits the number of cases in which the decision to migrate was taken by the parents - the results are similar if we use a different age threshold such as 18 years of age. As shown in Table 2, the main base sample consists of 1,277,062 observations on UK-born individuals and 155,017 observations on foreign-born individuals. Of the foreign-born, $47 \% \mathrm{mi}-$ grated for work reasons, $25 \%$ for family reasons, $14 \%$ for study and $4 \%$ for asylum reasons.

The main empirical analysis consists of estimating a series of linear probability models with the dependent variable being a dummy equal to one if the respondent is in self-employment $\left(y_{i}\right)$. As shown in Table 2, and in line with other studies, migrants in the UK are more likely to engage in self-employment than the UK-born, but the difference is not large (i.e. $15 \%$ vs $16 \%$ ). This, however, masks differences across groups based on reason for immigration. For instance, $15 \%$ of those who migrated for work reasons (i.e. "economic" migrants) are in selfemployment versus $23 \%$ of asylum migrants.

We start the analysis by estimating a series of regressions along the following lines:

$y_{i}=\alpha+\varphi M_{i}+\theta X_{i}+\gamma_{l}+\delta_{t}+\sigma_{q}+u_{i}$.

$M_{i}$ is a dummy variable indicating that the respondent was not born in the UK. $X_{i}$ represents a series of controls, including age, education, ethnicity, gender, religion and a dummy for EU nationality. Table 3 reports the means of individual characteristics for each of the groups. ${ }^{7}$ We also include local authority dummies $\left(\gamma_{l}\right)$, year dummies $\left(\delta_{t}\right)$ and quarter dummies $\left(\sigma_{q}\right)$ in the

\footnotetext{
${ }^{7}$ Tables A1 and $\mathrm{A} 5$ in the online appendix provide the definitions of all the variables and the correlation coefficients between these variables.
} 
Table 2 Composition of sample

\begin{tabular}{llll}
\hline & Observations & Proportion of sample (in \%) & Proportion of self-employment (in \%) \\
\hline Full sample & & 14.8 \\
UK-born & $1,277,062$ & 89.2 & 16.2 \\
Foreign-born & 155,017 & 10.8 & 15.7 \\
Foreign-born, by reason for immigration & & 15.1 \\
Study & 22,189 & 14.3 & 16.3 \\
Economic & 72,529 & 46.8 & 22.8 \\
Family & 38,467 & 24.8 & 19.5 \\
Asylum & 6005 & 3.9 & 15.0 \\
Other & 15,827 & 10.2 & \\
All & $1,432,079$ & 100.0 & \\
\hline
\end{tabular}

The sample is limited to employed respondents between the ages of 25 and 64 . For foreign-born respondents, we impose the additional restriction that migration must have occurred at age 16 or later

estimations. All estimations include robust standard errors. The coefficient $\varphi$ provides information on differences in the propensity to engage in self-employment between the foreign-born and the UK-born.

Next we explore the role of reason for immigration and test our hypotheses. In order to test H1, we estimate:

$y_{i}=\alpha+\sum_{j=1}^{5} \beta_{j} R_{j i}+\theta X_{i}+\gamma_{l}+\delta_{t}+\sigma_{q}+u_{i}$.

In this case, $R_{j i}$ are dummy variables indicating that the respondent migrated for study, work, family, asylum and other reasons. The control group are the UK-born. The discussion of the estimates from Eq. (5) focuses on the $\beta \mathrm{s}$ as these provide information on $\mathrm{H} 1$. Note that the interpretation of these results is descriptive as there is no exogenous factor affecting reason for immigration.

Next, we explore the role of length of residence in the UK. For this purpose, we limit the analysis to UK-born respondents and each of the migrant groups and estimate:

$$
\begin{aligned}
y_{i}= & \alpha+\beta R_{i}+\tau_{1} T_{i}+\tau_{2} T_{i}^{2}+\theta X_{i}+\gamma_{l}+\delta_{t}+\sigma_{q} \\
& +u_{i .}
\end{aligned}
$$

where $T_{i}$ represents the number of years since the person moved to the UK. This variable is set to zero for the UKborn. The coefficients $\tau_{1}$ and $\tau_{2}$ provide information for $\mathrm{H} 2$. We illustrate these relationships graphically for ease of interpretation. The analysis relies on 44 cross sections, and while we are mindful of the fact that the estimations are, as such, not adjusted for possible cohort specific differences and cannot account for those within each cohort who have returned to their country of origin, it is still possible to identify several interesting patterns. ${ }^{8}$

Subsequently, we explore the implications of the presence of compatriot networks for self-employment. For this purpose, we limit the sample to foreign-born respondents only and estimate the followiing:

$$
\begin{aligned}
y_{i}= & \alpha+\sum_{j=1}^{5} \beta_{j} R_{j i}+\kappa C_{i}+\sum_{j=1}^{5} \chi_{j} R_{j i} \times C_{i} \\
& +\theta X_{i}+\gamma_{l}+\delta_{t}+\sigma_{q}+u_{i} .
\end{aligned}
$$

where $C_{i}$ is the size of the compatriot population as a share of the local authority's population. The coefficient on the interaction between $R_{j i}$ and $C_{i}$ provides information on H3. Location is not random for any of the groups as individuals self-select into particular locations. For this reason, we refrain from making statements about causal relationships related to networks and emphasise that the purpose is to explore the statistical association between the presence of networks and self-employment.

Next, we separate the foreign-born sample between those coming from EU and non-EU countries and estimate regressions along the same lines of Eq. (5), with UK-nationals who were born outside the UK excluded from the sample. These estimations provide insights on H4. Migrants from Iceland, Lichtenstein, Norway and Switzerland are included in the EU group because they have similar access to the UK labour market as EU migrants. In the main estimations, we do not include those who migrated for asylum as the sample is relative-

\footnotetext{
${ }^{8}$ The Online Appendix reports the coefficients for $\tau_{1}$ and $\tau_{2}$ (Table A6). We also show the results for additional estimations using duration in the UK as a percentage of the respondent's age as an alternative measure of duration in the country (Figure A1).
} 
Table 3 Mean of key demographic characteristics

\begin{tabular}{|c|c|c|c|c|c|c|c|c|c|}
\hline & \multicolumn{3}{|l|}{ All } & \multicolumn{3}{|l|}{ Employees } & \multicolumn{3}{|l|}{ Self-employed } \\
\hline & Age left education & Age & Male & Age left education & Age & Male & Age left education & Age & Male \\
\hline UK-born & 17.96 & 44.66 & 0.52 & 17.97 & 44.24 & 0.49 & 17.89 & 47.09 & 0.68 \\
\hline Foreign-born & 20.44 & 40.42 & 0.53 & 20.51 & 40.04 & 0.51 & 20.06 & 42.35 & 0.66 \\
\hline Study migrant & 22.43 & 39.81 & 0.52 & 22.47 & 39.25 & 0.51 & 22.23 & 42.85 & 0.61 \\
\hline Economic migrant & 20.53 & 39.07 & 0.61 & 20.62 & 38.78 & 0.59 & 20.03 & 40.72 & 0.75 \\
\hline Family migrant & 19.76 & 42.03 & 0.36 & 19.81 & 41.71 & 0.34 & 19.49 & 43.70 & 0.50 \\
\hline Asylum migrant & 18.16 & 42.42 & 0.73 & 18.12 & 42.44 & 0.69 & 18.28 & 42.37 & 0.87 \\
\hline Other migrant & 19.69 & 42.74 & 0.50 & 19.70 & 42.25 & 0.47 & 19.66 & 44.79 & 0.64 \\
\hline Total & 18.22 & 44.20 & 0.52 & 18.24 & 43.79 & 0.49 & 18.14 & 46.53 & 0.68 \\
\hline
\end{tabular}

Age left education refers to the age at which the respondent left continuous full-time education

ly small for the EU group, but the Online Appendix reports the regression results with this group included.

Finally, we limit the sample to those who are in selfemployment and examine the relationship between reason for immigration and different types of self-employment. The LFS contains no information on earnings from self-employment or motivations to enter self-employment. Therefore, we focus on two different aspects: the number of workers employed by the self-employed and the skill level of the self-employment activity. For the number of workers employed, we start the analysis by using a dummy equal to one if the respondent employs any additional workers as the dependent variable. In a separate regression, we use a dummy equal to one if the respondent employs more than ten additional workers. For the skill level of the self-employment activity, we use (1) a dummy equal to one if the activity relates to managerial or professional tasks and (2) a dummy equal to one if the activity relates to routine or elementary tasks (e.g. cleaning, security), respectively, in separate regressions.

\section{Results}

\subsection{Likelihood of self-employment}

Panel A of Table 4 shows that foreign-born individuals are more likely to engage in self-employment than the UK-born. Focusing on column 7, which includes the full set of controls, the estimates suggest that the foreignborn are 1.6 percentage points more likely to engage in self-employment than the UK-born. However, this result masks key differences among migrant groups with different reasons for immigration. Panel B of Table 4 reports the results of the regressions that include the set of dummies for reason for immigration (Eq. (5)). Focusing again on column 7 , estimates suggest that those who migrated for study and work reasons are not much different from the UK-born in their likelihood of engaging in self-employment. On the other hand, those who migrated for family reasons are 3 percentage points more likely to engage in self-employment than the UK-born. Those who migrated for asylum reasons are 6 percentage points more likely to do so. These results support the argument made in $\mathrm{H} 1$, that is, the likelihood of engaging in self-employment is greater for groups that receive a lower reward in waged employment.

While not the main purpose of our analysis, some interesting results are worth highlighting from the demographic control variables. Females are 9 percentage points less likely to engage in self-employment relative to males. So are those who report their ethnicity as Pakistani in comparison to the White-British group. ${ }^{9}$ Note that adding controls for ethnicity leads to some changes in the coefficients of reason for immigration (i.e. column 4 versus column 5). In particular, the likelihood of self-employment of asylum migrants increases from 5.6 percentage points to 8.2 percentage points (both relative to the UK-born), although with little change to the overall story and patterns. ${ }^{10}$ Religion also seems to play a role, with those identifying themselves

\footnotetext{
${ }^{9}$ The category Pakistani refers to all those who identified with the ethnic category, regardless of country of birth.

${ }^{10}$ See Levie (2007) for further discussion of the role of ethnicity in determining self-employment in the UK.
} 
Table 4 Differences in the probability of self-employment relative to the UK-born

\begin{tabular}{|c|c|c|c|c|c|c|c|}
\hline & (1) & (2) & (3) & (4) & $(5)$ & $(6)$ & $(7)$ \\
\hline \multicolumn{8}{|c|}{ Panel A: Including foreign-born dummy } \\
\hline Foreign-born & $\begin{array}{l}0.014 * * * \\
(14.08)\end{array}$ & $\begin{array}{l}0.013 * * * \\
(12.77)\end{array}$ & $\begin{array}{l}0.007 * * * \\
(6.68)\end{array}$ & $\begin{array}{l}0.017 * * * \\
(16.63)\end{array}$ & $\begin{array}{l}0.021 * * * \\
(17.68)\end{array}$ & $\begin{array}{l}0.026^{* * * *} \\
(20.62)\end{array}$ & $\begin{array}{l}0.016 * * * \\
(9.15)\end{array}$ \\
\hline \multicolumn{8}{|c|}{ Panel B: Including reason for immigration dummies } \\
\hline Study migrant & $\begin{array}{l}0.009 * * * \\
(3.70)\end{array}$ & $\begin{array}{l}0.008 * * * \\
(3.27)\end{array}$ & $\begin{array}{l}-0.001 \\
(-0.42)\end{array}$ & $\begin{array}{l}0.012 * * * \\
(4.66)\end{array}$ & $\begin{array}{l}0.020 * * * \\
(7.49)\end{array}$ & $\begin{array}{l}0.022^{* * * *} \\
(8.20)\end{array}$ & $\begin{array}{l}0.009 * * * \\
(3.23)\end{array}$ \\
\hline Economic migrant & $\begin{array}{l}0.002 * \\
(1.69)\end{array}$ & $\begin{array}{l}0.001 \\
(0.55)\end{array}$ & $\begin{array}{l}-0.004 * * * \\
(-3.22)\end{array}$ & $\begin{array}{l}0.002 \\
(1.42)\end{array}$ & $\begin{array}{l}0.008 * * * \\
(5.32)\end{array}$ & $\begin{array}{l}0.015^{* * * *} \\
(10.04)\end{array}$ & $\begin{array}{l}-0.003 \\
(-1.34)\end{array}$ \\
\hline Family migrant & $\begin{array}{l}0.015 * * * \\
(7.68)\end{array}$ & $\begin{array}{l}0.014 * * * \\
(7.14)\end{array}$ & $\begin{array}{l}0.012 * * * \\
(6.07)\end{array}$ & $\begin{array}{l}0.034 * * * \\
(17.37)\end{array}$ & $\begin{array}{l}0.035 * * * \\
(16.37)\end{array}$ & $\begin{array}{l}0.036^{* * *} \\
(16.63)\end{array}$ & $\begin{array}{l}0.025 * * * \\
(10.66)\end{array}$ \\
\hline Asylum migrant & $\begin{array}{l}0.080 * * * \\
(14.70)\end{array}$ & $\begin{array}{l}0.078 * * * \\
(14.46)\end{array}$ & $\begin{array}{l}0.073 * * * \\
(13.46)\end{array}$ & $\begin{array}{l}0.056^{* * *} \\
(10.18)\end{array}$ & $\begin{array}{l}0.082 * * * \\
(14.52)\end{array}$ & $\begin{array}{l}0.070 * * * \\
(12.32)\end{array}$ & $\begin{array}{l}0.063 * * * \\
(10.92)\end{array}$ \\
\hline Other migrant & $\begin{array}{l}0.047 * * * \\
(14.84)\end{array}$ & $\begin{array}{l}0.046 * * * \\
(14.57)\end{array}$ & $\begin{array}{l}0.035 * * * \\
(11.02)\end{array}$ & $\begin{array}{l}0.041 * * * \\
(12.98)\end{array}$ & $\begin{array}{l}0.048 * * * \\
(14.96)\end{array}$ & $\begin{array}{l}0.048 * * * \\
(14.91)\end{array}$ & $\begin{array}{l}0.036 * * * \\
(10.41)\end{array}$ \\
\hline Education & & & & $\begin{array}{l}-0.000 * * * \\
(-4.38)\end{array}$ & $\begin{array}{l}-0.000 * * * \\
(-3.24)\end{array}$ & $\begin{array}{l}-0.000 * * \\
(-2.53)\end{array}$ & $\begin{array}{l}-0.000^{\text {*** }} \\
(-2.61)\end{array}$ \\
\hline Age of respondent & & & & $\begin{array}{l}0.003 * * * \\
(13.97)\end{array}$ & $\begin{array}{l}0.004 * * * \\
(15.00)\end{array}$ & $\begin{array}{l}0.004 * * * \\
(15.18)\end{array}$ & $\begin{array}{l}0.004 * * * \\
(15.62)\end{array}$ \\
\hline Age of respondent square & & & & $\begin{array}{l}-0.000 \\
(-1.54)\end{array}$ & $\begin{array}{l}-0.000 * * \\
(-2.54)\end{array}$ & $\begin{array}{l}-0.000 * * * \\
(-2.59)\end{array}$ & $\begin{array}{l}-0.000 * * * \\
(-2.92)\end{array}$ \\
\hline Female & & & & $\begin{array}{l}-0.097 * * * \\
(-166.43)\end{array}$ & $\begin{array}{l}-0.095 * * * \\
(-159.78)\end{array}$ & $\begin{array}{l}-0.092 * * * \\
(-152.04)\end{array}$ & $\begin{array}{l}-0.092 * * * \\
(-152.24)\end{array}$ \\
\hline Mixed race & & & & & $\begin{array}{l}0.006^{*} \\
(1.71)\end{array}$ & $\begin{array}{l}0.004 \\
(0.99)\end{array}$ & $\begin{array}{l}0.006 \\
(1.47)\end{array}$ \\
\hline Indian & & & & & $\begin{array}{l}-0.028 * * * \\
(-12.38)\end{array}$ & $\begin{array}{l}-0.056^{* * * *} \\
(-16.70)\end{array}$ & $\begin{array}{l}-0.047 * * * \\
(-13.64)\end{array}$ \\
\hline Pakistani & & & & & $\begin{array}{l}0.125 * * * \\
(30.77)\end{array}$ & $\begin{array}{l}0.080 * * * \\
(15.03)\end{array}$ & $\begin{array}{l}0.085 * * * \\
(15.86)\end{array}$ \\
\hline Bangladeshi & & & & & $\begin{array}{l}0.023 * * * \\
(3.49)\end{array}$ & $\begin{array}{l}-0.021 * * * \\
(-2.88)\end{array}$ & $\begin{array}{l}-0.015^{* *} \\
(-1.98)\end{array}$ \\
\hline Chinese & & & & & $\begin{array}{l}0.011 * * \\
(2.07)\end{array}$ & $\begin{array}{l}0.003 \\
(0.52)\end{array}$ & $\begin{array}{l}0.013 * * \\
(2.34)\end{array}$ \\
\hline Other Asian & & & & & $\begin{array}{l}-0.038 * * * \\
(-11.32)\end{array}$ & $\begin{array}{l}-0.052 * * * \\
(-14.46)\end{array}$ & $\begin{array}{l}-0.041 * * * \\
(-11.14)\end{array}$ \\
\hline Black afro/Caribbean & & & & & $\begin{array}{l}-0.061 * * * \\
(-27.41)\end{array}$ & $\begin{array}{l}-0.060 * * * \\
(-26.87)\end{array}$ & $\begin{array}{l}-0.053 * * * \\
(-22.95)\end{array}$ \\
\hline Other & & & & & $\begin{array}{l}-0.011 \text { *** } \\
(-3.49)\end{array}$ & $\begin{array}{l}-0.028 * * * \\
(-8.35)\end{array}$ & $\begin{array}{l}-0.021 * * * \\
(-6.20)\end{array}$ \\
\hline Buddhist & & & & & & $\begin{array}{l}0.038 * * * \\
(6.93)\end{array}$ & $\begin{array}{l}0.040 * * * \\
(7.27)\end{array}$ \\
\hline Hindu & & & & & & $\begin{array}{l}0.015 * * * \\
(3.87)\end{array}$ & $\begin{array}{l}0.017 * * * \\
(4.41)\end{array}$ \\
\hline Jewish & & & & & & $\begin{array}{l}0.093 * * * \\
(14.89)\end{array}$ & $\begin{array}{l}0.095 * * * \\
(15.18)\end{array}$ \\
\hline
\end{tabular}


Table 4 (continued)

\begin{tabular}{|c|c|c|c|c|c|c|c|}
\hline & (1) & (2) & (3) & (4) & (5) & (6) & (7) \\
\hline \multirow[t]{2}{*}{ Muslim } & & & & & & $0.054 * * *$ & $0.056^{* * *}$ \\
\hline & & & & & & (14.64) & $(15.16)$ \\
\hline \multirow[t]{2}{*}{ Sikh } & & & & & & $0.088 * * *$ & $0.085 * * *$ \\
\hline & & & & & & (16.36) & $(15.75)$ \\
\hline \multirow[t]{2}{*}{ Any other religion } & & & & & & $0.063 * * *$ & $0.064 * * *$ \\
\hline & & & & & & (20.04) & $(20.15)$ \\
\hline \multirow[t]{2}{*}{ No religion at all } & & & & & & $0.013 * * *$ & $0.013 * * *$ \\
\hline & & & & & & (17.99) & $(18.53)$ \\
\hline \multirow[t]{2}{*}{ EU national } & & & & & & & $0.027 * * *$ \\
\hline & & & & & & & (11.62) \\
\hline Year dummy & No & Yes & Yes & Yes & Yes & Yes & Yes \\
\hline Quarter dummy & No & Yes & Yes & Yes & Yes & Yes & Yes \\
\hline LA dummy & No & No & Yes & Yes & Yes & Yes & Yes \\
\hline Observations & $1,432,079$ & $1,432,079$ & $1,432,079$ & $1,424,949$ & $1,372,343$ & $1,330,453$ & $1,330,384$ \\
\hline
\end{tabular}

The table shows the coefficients and t-statistics (in parenthesis) from linear probability models. The sample comprises those in employment. The base group is UK-born. The dependent variable is a dummy, which takes value 1 for those in self-employment

$* p<0.1 ; * *<<0.05 ; * * *<0.01$ statistical significance levels

as Jewish and Sikh being about 9 to 10 percentage points more likely to engage in self-employment compared to Christians. Finally, EU nationals are 3 percentage points more likely to be in self-employment than others. We do not report the coefficients for the control variables in the remaining tables of the paper for reasons of space. ${ }^{11}$

\subsection{Length of residence in the UK}

Figure 2 plots the combined estimated coefficients $\tau_{1}$ and $\tau_{2}$ as time in the UK increases. The zero line therein represents UK-born workers as the benchmark.

Two general points emerge from Fig. 2. First, we note that the recently arrived migrants have, on average, a lower likelihood of self-employment than the UK-born across all groups. Second, after 12 years in the country, all migrant groups have higher average levels of selfemployment than the UK-born. The increase in selfemployment rates over time can relate to many factors

\footnotetext{
${ }^{11}$ Table A2 in the online appendix reports the results from a regression that includes country of origin controls. We cannot include the UKborn in this estimation and therefore use those who migrated for work reasons as the control group. The result (i.e. ranking) is consistent with our earlier findings. The results also remain robust to clustering standard errors at the region of residence level and to restricting the sample to observations from the first wave of the rotatory panel sample - see online appendix Tables A3 and A4.
}

including changes in legal status (e.g. obtaining permanent settlement or UK citizenship).

Regarding H2, note that the line is initially steepest for asylum migrants and flattest for study migrants. In fact, for most of the period in the figure, asylum migrants are more likely to engage in self-employment than the other groups. The dynamics suggested by Fig. 2 do not coincide exactly with $\mathrm{H} 2$, as there is not a simple convergence pattern to the UK-born for any of the groups. However, there are clear differences in the adjustment in selfemployment rates for the different migrant groups as length of residence in the UK increases.

\subsection{Role of compatriot networks}

Table 5 presents the results for the estimations in which we include compatriot networks as an additional variable, along with interactions between compatriot networks and the reason for immigration dummies. The coefficients for these interactions shed light on H3. The base category in this case is economic migrants. The results suggest that a 1 percentage point increase in the share of compatriots in the local authority of residence is associated with a decrease in the likelihood of selfemployment of 0.6 percentage points for study migrants (i.e. interaction between reason for immigration and population share of compatriots). In comparison, a 1 
Fig. 2 Relationship between length of residence in the UK and the self-employment probability of each migrant group relative to the UK-born (in percentage points). The zero line represents the UK-born. See the Online Appendix for the regressions coefficients used to construct the figure

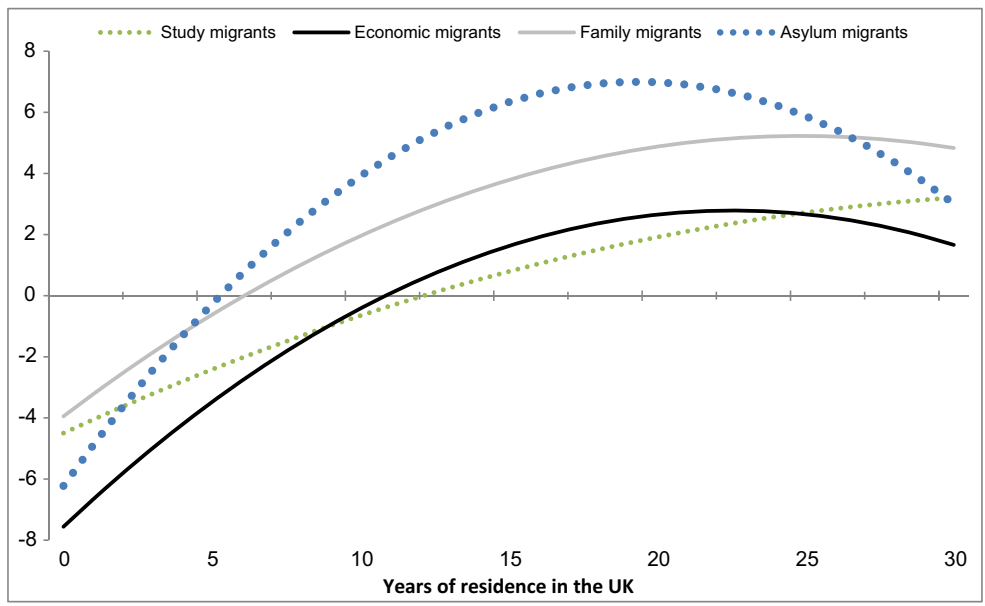

percentage point increase in the of share compatriots in the local authority of residence is associated with an increase in this likelihood of 0.5 percentage points for asylum migrants.

These results are in line with the argument that compatriot networks may play dissimilar roles for individuals who migrated for different reasons and, in essence, augment differences across groups (H3). We reiterate that this estimate captures a conditional correlation given that the location of individuals across the UK is not random.

\subsection{EU and non-EU}

Table 6 replicates the analysis from Eqs. (4) and (5) separately for migrants coming from EU and non-EU countries. Looking at panel A, we see that those coming from the EU are more likely to engage in selfemployment than the UK-born (column 2), while those coming from outside the EU are as likely as the UKborn to engage in self-employment (column 4).

Concerning H4, the results suggest that immigration policy and related initial restrictions could play a key role in determining the self-employment rate of migrants. The results are consistent with $\mathrm{H} 4$, as study and economic EU migrants have a higher propensity of selfemployment compared to their non-EU counterparts. The differences are substantial. For instance, while economic migrants from the EU are 2 percentage points more likely than the UK-born to engage in self-employment, those from outside the EU are 2 percentage points less likely to engage in self-employment. As explained above, non-EU economic and study migrants face major initial legal restrictions on taking self-employment.

\subsection{Characteristics of self-employment}

This section limits the sample to only those who are in self-employment and examine how reason for immigration relates to different characteristics of self-employment. In general, self-employed foreign-born individuals are less likely to have employees compared to the UK born. Looking into the more nuanced analysis, the estimates in column 1 of Table 7 suggest that whereas those who migrated for asylum reasons are 5 percentage points more likely than the UK-born to employ someone else, those who migrated for economic reasons are 5 percentage points less likely to do so. The gap for those who migrated for economic reasons declines to 2 percentage points and that for those who migrated for asylum fades away, when we account for the full set of controls (column 2). In columns 3 and 4, the dependent variable indicates whether the respondent employs more than 10 workers. The results suggest that migrants who are in self-employment are less likely to employ more than 10 workers relative to the UK-born. This does not vary much by reason for immigration. All migrant groups are close to 2 or 3 percentage points less likely to employ more than 10 workers relative to the UK-born.

Turning to results on the skill level of the selfemployment activity, Table 8 suggests that migrants who are in self-employment are 7 percentage points less likely to be doing managerial or professional tasks than the UK-born. The gap is substantially larger for those who migrated for asylum reasons (16 percentage points), compared to those who migrated for work or study reasons. Consistent with this, the self-employed who migrated for asylum reasons are 24 percentage 
Table 5 Relationship between the presence compatriots and the probability of self-employment (foreign-born only). Comparison group is economic migrants

\begin{tabular}{|c|c|c|}
\hline & (1) & $(2)$ \\
\hline Study migrant & $\begin{array}{l}0.034 * * * \\
(8.47)\end{array}$ & $\begin{array}{l}0.034 * * * \\
(8.60)\end{array}$ \\
\hline Family migrant & $\begin{array}{l}0.033 * * * \\
(9.81)\end{array}$ & $\begin{array}{l}0.034 * * * \\
(9.94)\end{array}$ \\
\hline Asylum migrant & $\begin{array}{l}0.044 * * * \\
(5.01)\end{array}$ & $\begin{array}{l}0.044 * * * \\
(5.10)\end{array}$ \\
\hline Other migrant & $\begin{array}{l}0.029 * * * \\
(5.79)\end{array}$ & $\begin{array}{l}0.029 * * * \\
(5.83)\end{array}$ \\
\hline $\begin{array}{l}\text { Population share of compatriots } \\
\quad \text { (PSC) }\end{array}$ & $\begin{array}{l}0.171 * * * \\
(3.84)\end{array}$ & $\begin{array}{l}-0.066 \\
(-0.95)\end{array}$ \\
\hline Total compatriots in LA & & $\begin{array}{l}0.000002 * * * \\
(4.11)\end{array}$ \\
\hline Study migrants $\times$ PSC & $\begin{array}{l}-0.561 * * * \\
(-6.11)\end{array}$ & $\begin{array}{l}-0.593 * * * \\
(-6.40)\end{array}$ \\
\hline Family migrants $\times$ PSC & $\begin{array}{l}-0.340 * * * \\
(-5.55)\end{array}$ & $\begin{array}{l}-0.360 * * * \\
(-5.87)\end{array}$ \\
\hline Asylum migrants $\times$ PSC & $\begin{array}{l}0.516^{*} \\
(1.86)\end{array}$ & $\begin{array}{l}0.507^{*} \\
(1.83)\end{array}$ \\
\hline Other migrants $\times$ PSC & $\begin{array}{l}0.157 \\
(1.43)\end{array}$ & $\begin{array}{l}0.149 \\
(1.36)\end{array}$ \\
\hline Demographic controls & Yes & Yes \\
\hline Year dummy & Yes & Yes \\
\hline Quarter dummy & Yes & Yes \\
\hline LA dummy & Yes & Yes \\
\hline Observations & 144,426 & 144,426 \\
\hline
\end{tabular}

The table shows the coefficients and t-statistics (in parenthesis) from linear probability models. The sample comprises those in employment. The base group is economic migrants. The dependent variable is a dummy, which takes value 1 for those in selfemployment. The coefficients of interest are the interactions between reason for immigration and population share of compatriots (PSC)

${ }^{*} p<0.1 ; * *<0.05 ; * * * p<0.01$ statistical significance levels

points more likely to be doing routine or elementary tasks relative to the UK born, a coefficient that is higher than that of the other migrant groups.

\section{Conclusion}

Our analysis suggests that differences in reason for immigration are an important determinant of self-
Table 6 Differences in the probability of self-employment relative to the UK-born (foreign-born grouped into EU-born and nonEU-born)

$\begin{array}{ll}\begin{array}{l}\text { UK-born and EU } \\ \text { migrants sample }\end{array} & \begin{array}{l}\text { UK-born and non-EU } \\ \text { migrants sample }\end{array}\end{array}$

\begin{tabular}{lll}
\hline 11 & $(2)$ & (3)
\end{tabular}

Panel A: Including foreign-born dummy

$$
\begin{array}{lllll}
\text { Foreign-born } & 0.011 * * * & 0.030 * * * & -0.010 * * * & 0.003 \\
& (7.77) & (18.81) & (-5.85) & (1.11)
\end{array}
$$

\begin{tabular}{|c|c|c|c|c|}
\hline $\begin{array}{l}\text { Study } \\
\text { migrant }\end{array}$ & $\begin{array}{l}-0.002 \\
(-0.51)\end{array}$ & $\begin{array}{l}0.018 * * * \\
(3.98)\end{array}$ & $\begin{array}{l}-0.016 \text { *** } \\
(-4.21)\end{array}$ & $\begin{array}{l}0.001 \\
(0.27)\end{array}$ \\
\hline $\begin{array}{c}\text { Economic } \\
\text { migrant }\end{array}$ & $\begin{array}{l}0.008 * * * \\
(4.81)\end{array}$ & $\begin{array}{l}0.023 * * * \\
(12.41)\end{array}$ & $\begin{array}{l}-0.020 * * * \\
(-7.49)\end{array}$ & $\begin{array}{l}-0.018 \text { *** } \\
(-5.70)\end{array}$ \\
\hline $\begin{array}{l}\text { Family } \\
\text { migrant }\end{array}$ & $\begin{array}{l}0.013 * * * \\
(3.21)\end{array}$ & $\begin{array}{l}0.052 * * * \\
(12.50)\end{array}$ & $\begin{array}{l}-0.015 * * * \\
(-5.08)\end{array}$ & $\begin{array}{l}0.009^{* * *} \\
(2.83)\end{array}$ \\
\hline $\begin{array}{l}\text { Other } \\
\text { migrant }\end{array}$ & $\begin{array}{l}0.047 * * * \\
(9.04)\end{array}$ & $\begin{array}{l}0.058 * * * \\
(10.92)\end{array}$ & $\begin{array}{l}0.051 * * * \\
(8.54)\end{array}$ & $\begin{array}{l}0.049 * * * \\
(8.15)\end{array}$ \\
\hline $\begin{array}{l}\text { Demographic } \\
\text { controls }\end{array}$ & No & Yes & No & Yes \\
\hline Year dummy & No & Yes & No & Yes \\
\hline $\begin{array}{l}\text { Quarter } \\
\text { dummy }\end{array}$ & No & Yes & No & Yes \\
\hline LA dummy & No & Yes & No & Yes \\
\hline Observations & $1,342,134$ & $1,245,859$ & $1,319,440$ & $1,225,556$ \\
\hline
\end{tabular}

Panel B: Including reason for immigration dummies

The table shows the coefficients and t-statistics (in parenthesis) from linear probability models. The sample comprises those in employment. The base group is the UK-born. The dependent variable is a dummy, which takes value 1 for those in selfemployment

$* p<0.1 ; * *<<0.05 ; * * * p<0.01$ statistical significance levels

employment among the UK's foreign-born workforce. The results suggest that expected differences in the reward to waged employment are likely to play a key role in this regard. Groups more likely to earn a higher reward in waged employment (i.e. study and economic migrants) are less likely to engage in self-employment, compared to those likely to be less rewarded (i.e. family and asylum migrants). The implications of compatriot networks and length of residence in the UK for the likelihood of self-employment also seem to be affected by reason for immigration. Overall, our results suggest that failing to account for reason for immigration can mask important factors related to the self-employment behaviour of migrants.

The results of the paper have implications for policymakers, the response of European countries to 
Table 7 Probability of having employees given self-employed

Has employees

(1)
(2)

$$
\begin{aligned}
& -0.025 * * * \\
& (-5.47)
\end{aligned}
$$

$$
-0.002
$$$$
(-0.30)
$$

Economic migrant

Study migrant

$-0.047 * * *$

$(-13.47)$

Family migrant

$$
-0.018 * * *
$$$$
(-3.76)
$$

Asylum migrant

$$
0.051 * * *
$$

Other migrant

$$
-0.039 * * *
$$$$
(-5.90)
$$

Demographic controls

Year dummy

Quarter dummy

LA dummy

Observations
No

No

No

No

214,380
$-0.023 * * *$

$(-3.90)$

$-0.035 * * *$

$(-5.94)$

$-0.009$

$(-0.70)$

$-0.034 * * *$

$(-4.59)$

Yes

Yes

Yes

Yes

198,479
Has more than 10 employees

(3)

(4)

The table shows the coefficients and t-statistics (in parenthesis) from linear probability models. The sample comprises those in selfemployment. The base group is the UK-born. The dependent variable is a dummy, which takes value 1 for those who report (1) having employees other than own partner in columns 1 and 2; and (2) having more than 10 employees in columns 3 and 4

$* p<0.1 ; * * p<0.05 ; * * p<0.01$ statistical significance levels

the "refugee crisis" and Brexit. The discussion below explores each of these areas.

\subsection{Policymakers}

The analysis suggests that route of entry into a country reflects a certain degree of common interests, social experiences, and legal restrictions that may affect the likelihood of engaging in self-employment in the short and long terms. Therefore, original reason for immigration should be a consideration in the creation of policies that aim to boost migrant entrepreneurship.

\subsection{The refugee crisis}

There has been a recent increase in the number of asylum applications in the EU because of the number of conflicts near Europe (i.e. the refugee crisis). Our results suggest that employed asylum migrants are substantially more likely to engage in self-employment than other migrants. Should these patterns also hold for refugees in other European countries (e.g. Germany), then the recent increase in asylum applications might result in an increase in the overall self-employment rate of migrants in Europe. A better understanding of selfemployment dynamics of refugees would help in addressing issues of labour market integration for those obtaining asylum in EU countries.

\subsection{Brexit}

The analysis suggests that migrants coming from EU countries have a higher propensity to engage in selfemployment compared to migrants from non-EU countries. This is the case regardless of reason for immigration, which suggests that a post-Brexit system that makes it overall more difficult for EU nationals to 
Table 8 Reason for immigration and occupation type of job (self-employed respondents only)

Professional or managerial

(1)

(2)

Routine or elementary

(3)

(4)

Panel A: Including foreign-born dummy

\begin{tabular}{|c|c|c|c|c|}
\hline Foreign-born & $\begin{array}{l}-0.003 \\
(-0.93)\end{array}$ & $\begin{array}{l}-0.074 * * * \\
(-14.25)\end{array}$ & $\begin{array}{l}0.103 * * * \\
(32.72)\end{array}$ & $\begin{array}{l}0.080^{* * * *} \\
(16.18)\end{array}$ \\
\hline \multicolumn{5}{|c|}{ Panel B: Including reason for immigration dummies } \\
\hline \multirow[t]{2}{*}{ Study migrant } & $0.143 * * *$ & $-0.047 * * *$ & $-0.015^{* *}$ & $0.035^{* * *}$ \\
\hline & $(17.36)$ & $(-5.11)$ & $(-2.06)$ & $(4.22)$ \\
\hline \multirow[t]{2}{*}{ Economic migrant } & -0.005 & $-0.045^{* * *}$ & $0.080 * * *$ & $0.090 * * *$ \\
\hline & $(-1.29)$ & $(-6.76)$ & $(17.57)$ & $(14.34)$ \\
\hline \multirow[t]{2}{*}{ Family migrant } & $-0.041 * * *$ & $-0.095 * * *$ & $0.174 * * *$ & $0.067 * * *$ \\
\hline & $(-8.18)$ & $(-14.39)$ & $(27.59)$ & $(9.35)$ \\
\hline \multirow[t]{2}{*}{ Asylum migrant } & $-0.142 * * *$ & $-0.163 * * *$ & $0.301 * * *$ & $0.239 * * *$ \\
\hline & $(-18.73)$ & $(-14.49)$ & $(22.30)$ & $(15.75)$ \\
\hline \multirow[t]{2}{*}{ Other migrant } & $-0.018 * *$ & $-0.082 * * *$ & $0.087 * * *$ & $0.072 * * *$ \\
\hline & $(-2.45)$ & $(-9.71)$ & $(10.16)$ & $(8.07)$ \\
\hline Demographic controls & No & Yes & No & Yes \\
\hline Year dummy & No & Yes & No & Yes \\
\hline Quarter dummy & No & Yes & No & Yes \\
\hline LA dummy & No & Yes & No & Yes \\
\hline Observations & 214,410 & 198,507 & 214,410 & 198,507 \\
\hline
\end{tabular}

The table shows the coefficients and t-statistics (in parenthesis) from linear probability models. The sample comprises those in selfemployment. The base group is the UK-born. The dependent variable is a dummy, which takes value 1 for those who report (1) being in a professional or managerial occupation in columns 1 and 2; and (2) being in a routine and elemental occupation in columns 3 and 4

$* p<0.1 ; * * p<0.05 ; * * p<0.01$ statistical significance levels

migrate to the UK could reduce the self-employment rate of the UK's foreign-born population in the future.

\subsection{Future research}

The analysis in this paper reveals several areas for future research. First, our analysis is limited to self-employment and future research can explore how reason for immigration relates to other definitions of entrepreneurship. Second, the role of different types of networks, such as those with high versus low self-employment intensity (Toussaint-Comeau 2012), could vary based on reason for immigration. Again, future research can explore this aspect. Third, the LFS does not include information on earnings from self-employment and, as such, it is not possible to explore the link between reason for immigration and earnings from self-employment. Data collection efforts should consider this gap. Finally, the UK immigration system shares similarities with those of other high-income countries, but there are also differences related to access to self-employment of different migrant groups, among others. Conducting the same type of research in other countries can provide insights on whether the findings here may hold in a different context.

Acknowledgements The data used come from the secured access version of the UK Labour Force Survey produced by the Office for National Statistics (ONS) and supplied by the UK Data Service (ONS 2018).

Funding information This study was funded by the Nuffield Foundation as part of the project "The Economic Integration of Refugees in the UK".

\section{Compliance with ethical standards}

Disclaimer The views expressed are those of the authors and not necessarily those of the Nuffield Foundation. The use of the data in this work does not imply the endorsement of ONS or the Secure Data Service at the UK Data Archive in relation to the interpretation or analysis of the data. 
Open Access This article is licensed under a Creative Commons Attribution 4.0 International License, which permits use, sharing, adaptation, distribution and reproduction in any medium or format, as long as you give appropriate credit to the original author(s) and the source, provide a link to the Creative Commons licence, and indicate if changes were made. The images or other third party material in this article are included in the article's Creative Commons licence, unless indicated otherwise in a credit line to the material. If material is not included in the article's Creative Commons licence and your intended use is not permitted by statutory regulation or exceeds the permitted use, you will need to obtain permission directly from the copyright holder. To view a copy of this licence, visit http://creativecommons.org/licenses/by/4.0/.

\section{References}

Andersson, L., \& Hammarstedt, M. (2015). Ethnic enclaves, networks and self-employment among middle eastern immigrants in Sweden. International Migration, 53, 27-40. https://doi.org/10.1111/j.1468-2435.2011.00714.x.

Batista, C., \& Umblijs, J. (2014). Migration, risk attitudes, and entrepreneurship: evidence from a representative immigrant survey. IZA J Migr, 3(1), 17. 2-17.25.

Blume, K., Ejrnæs, M., Nielsen, H. S., \& Würtz, A. (2009). Labor market transitions of immigrants with emphasis on marginalization and self-employment. Journal of Population Economics, 22, 881-890. https://doi.org/10.1007/s00148008-0191-X.

Borjas, G. J. (1982). The earnings of male Hispanic immigrants in the United States. Industrial and Labor Relations Review, 35, 343-353. https://doi.org/10.1177/001979398203500304.

Borjas, G. J., \& Bronars, S. G. (1989). Consumer discrimination and self-employment. Journal of Political Economy, 97(3), 581-605 http://www.jstor.org/stable/1830456.

Brück, T., Mahe, C., \& Naudé, W. (2018). Return migration and self-employment: evidence from Kyrgyzstan. IZA Discussion Paper No. 11332.

Clark, K., \& Drinkwater, S. (2000). Pushed in or pulled out? Selfemployment among ethnic minorities in England and Wales. Labour Economics, 7, 603-628. https://doi.org/10.1016 /S0927-5371(00)00015-4.

Clark, K., \& Drinkwater, S. (2010). Recent trends in minority ethnic entrepreneurship in Britain. International Small Business Journal, 28, 136-146. https://doi.org/10.1177 /0266242609355831.

Clark, K., Drinkwater, S., \& Robinson, C. (2017). Selfemployment among migrant groups: new evidence from England and Wales. Small Business Economics, 48, 10471069. https://doi.org/10.1007/s11187-016-9804-z.

Constant, A. F., \& Zimmermann, K. F. (2005). Legal status at entry, economic performance, and self-employment proclivity: a bi-national study of immigrants. IZA Discussion Paper No. 1910.

Davidsson, P., \& Honig, B. (2003). The role of social and human capital among nascent entrepreneurs. Journal of Business Venturing, 18(3), 301-331. https://doi.org/10.1016/S08839026(02)00097-6.
Fairlie, R. W., \& Lofstrom, M.. (2015). Immigration and entrepreneurship. CESIFO Working Paper no. 529.

Fairlie, R. W., \& Meyer, B. D. (1996). Ethnic and racial selfemployment differences and possible explanations. The Journal of Human Resources, 31(4), 757-793. https://doi. org/10.2307/146146.

Granovetter, M. (1995). Getting a job: a study of contacts and careers. University of Chicago press.

Hammarstedt, M. (2004). Self-employment among immigrants in Sweden - an analysis of intragroup differences. Small Business Economics, 23, 115-126. https://doi.org/10.1023 /B:SBEJ.0000027664.58874.62.

Hansen, N. H., \& Cardenas, G. C. (1988). Immigrant and native ethnic enterprises in Mexican American neighborhoods: differing perceptions of Mexican American workers. International Migration Review, 22, 226-242. https://doi. org $/ 10.2307 / 2546648$.

Hart, D. M., \& Acs, Z. J. (2011). Immigration and high-impact, high-tech entrepreneurship. Brookings Institution, Center for Technology Innovation.

Jansen, M., de Kok, J., van Spronsen, J., \& Willemsen, S. (2003). Immigrant entrepreneurship in the Netherlands. Research report H200304, Scientific Analysis of Entrepreneurship and SMEs (SCALES).

Kerr, S. P., \& Kerr, W. R. (2017). Immigrant entrepreneurship. Harvard Business School, working paper 17-011.

Levie, J. D. (2007). Immigration, in-migration, ethnicity and entrepreneurship in the United Kingdom. Small Business Economics, 28, 143-169. https://doi.org/10.1007/s11187006-9013-2.

Levie, J. D., \& Smallbone, D. (2009). Immigration, ethnicity and entrepreneurial behaviour. Perspectives on Entrepreneurship, 1, 157-180 http://www.jstor.org/stable/40229524.

Martín-Montaner, J., Serrano-Domingo, G., \& Requena-Silvente, F. (2018). Networks and self-employed migrants. Small Business Economics, 51, 735-755. https://doi.org/10.1007 /s11187-017-9962-7.

McMullen, J. S., \& Shepherd, D. (2006). Entrepreneurial action and the role of uncertainty in the theory of the entrepreneur. Academy of Management Review, 31(1), 132-152. https://doi.org/10.5465/amr.2006.19379628.

Miera, F. (2008). Transnational strategies of polish migrant entrepreneurs in trade and small business in Berlin. Journal of Ethnic and Migration Studies, 34, 753-770. https://doi. org/10.1080/13691830802106010.

Migration and Remittances: Recent Developments and Outlook, Migration and Development Brief 29, World Bank, April 2018.

Min, P. G. (1989). Some positive functions of ethnic business for an immigrant community: Koreans in Los Angeles. Final Report, National Science Foundation.

OECD. (2010). Entrepreneurship and migrants. OECD working party on SMEs and entrepreneurship. OECD: Paris.

OECD. (2018). International migration outlook 2018. OECD: Paris.

Office for National Statistics. (2018). Population of the United Kingdom by country of birth and nationality. London: ONS.

Office for National Statistics. Social Survey Division, Northern Ireland Statistics and Research Agency. Central Survey Unit. (2018). Quarterly Labour Force Survey, 1992-2018: Secure 
Access. [data collection]. 13th Edition. UK Data Service. SN: 6727. https://doi.org/10.5255/UKDA-SN-6727-14

Ramoglou, S., \& Tsang, E. W. (2016). A realist perspective of entrepreneurship: opportunities as propensities. Academy of Management Review, 41(3), 410-434. https://doi. org/10.5465/amr.2014.0281.

Ruiz, I., \& Vargas-Silva, C. (2018). Differences in labour market outcomes between natives, refugees and other migrants in the UK. Journal of Economic Geography, 18, 855-885. https://doi.org/10.1093/jeg/lby027.

Sumption, M., \& Vargas-Silva, C. (2019). Love is not all you need: income requirement for visa sponsorship of foreign family members. Journal of Economics, Race, and Policy, 2(1-2), 62-76. https://doi.org/10.1007/s41996-018-0022-8.

Toussaint-Comeau, M. (2012). Ethnic social networks and selfemployment of immigrant men in the US. Eastern Economic Journal, 38(1), 74-98. https://doi.org/10.1057/eej.2010.52.

Vandor, P., \& Franke, N. (2016). See Paris and... found a business? The impact of cross-cultural experience on opportunity recognition capabilities. Journal of Business Venturing, 31(4), 388- 407. https://doi.org/10.1016/j.jbusvent.2016.03.003.
Vargas-Silva, C. (2016a). Highly skilled migrant workers and the UK business cycle. Population, Space and Place, 22(5), 457-470. https://doi.org/10.1002/psp.1867.

Vargas-Silva, C. (2016b). EU migration to and from the UK after Brexit. Intereconomics, 51(5), 251-255. https://doi. org/10.1007/s10272-016-0613-z.

Vargas-Silva, C. (2017). Remittances sent to and from the forcibly displaced. The Journal of Development Studies, 53(11), 18351848. https://doi.org/10.1080/00220388.2016.1234040.

Volery, T. (2007). Ethnic entrepreneurship: a theoretical framework. In L. P. Dana (Ed.), Handbook of research on ethnic minority entrepreneurship: a co-evolutionary view on resource management (pp. 30-41). Edward Elgar Publishing.

Zhou, M. (2004). Revisiting ethnic entrepreneurship: convergencies, controversies, and conceptual advancements 1 . International Migration Review, 38(3), 1040-1074. https://doi.org/10.1111/j.1747-7379.2004.tb00228.x.

Publisher's note Springer Nature remains neutral with regard to jurisdictional claims in published maps and institutional affiliations. 